\title{
SISTEM PENDUKUNG KEPUTUSAN PENENTUAN RANKING KENAIKAN GAJI STAFF DAN KARYAWAN
}

\author{
Poningsih ${ }^{1}$ \\ AMIK Tunas Bangsa Pematangsiantar \\ Jl. Jendral Sudirman Blok A No. 1/2/3 Pematangsiantar \\ poningsih@amiktunasbangsa.ac.id ${ }^{1}$
}

\begin{abstract}
Abstrak
Abstrak-Saat ini AMIK dan STIKOM Tunas Bangsa memiliki kurang lebih 100 orang pegawai (staff dan karyawan). Masingmasing pegawai memiliki gaji yang berbeda dan beragam. Setiap tahun nya, manajemen AMIK dan STIKOM Tunas Bangsa memberikan kenaikan gaji kepada para pegawainya. Tetapi jumlah kenaikan nya sangatlah beragam. Sistem pendukung keputusan ini nantinya akan memberikan rekomendasi kepada pihak manajemen berupa perankingan kinerja dari pegawai. Ada beberapa factor yang digunakan didalam sistem pendukung keputusan ini, antara lain masa kerja, pendidikan dan kinerja. Metode yang digunakan adalah Multi-objective Optimization on The Basis of Ratio Analysis (MOORA). Dimana kelebihan MOORA adalah memiliki tingkat selektifitas yang baik karena dapat menentukan tujuan dari kriteria yang bertentangan.
\end{abstract}

Kata Kunci : Sistem Pendukung Keputusan, Perankingan, Gaji Pegawai, rekomendasi, MOORA

\section{Pendahuluan}

AMIK dan STIKOM Tunas Bangsa adalah Yayasan yang bergerak dibidang pendidikan (Perguruan Tinggi). Pegawai AMIK dan STIKOM Tunas Bangsa berjumlah kurang lebih 100 orang. Setiap tahun nya pihak manajemen memberikan kenaikan gaji kepada para pegawai. Namun besar jumlah kenaikan gaji nya masing-masing berbeda antar pegawai. Untuk menentukan berapa besar jumlah kenaikan tersebut, terkadang pihak manajemen sedikit mengalami kesulitan. Untuk menentukan siapa pegawai 
yang diberikan jumlah kenaikan paling tinggi juga agak sulit. Hal ini dikarenakan keputusan terkait hal tersebut belum melalui pertimbangan-pertimbangan yang standart. Contoh nya belum adanya faktor atau kriteria yang dapat membantu mempermudah pengambilan keputusan tersebut.

Berawal dari adanya permasalahan tersebut, maka perlu adanya solusi yaitu dengan mengaplikasikan Sistem Pendukung Keputusan penentuan ranking kenaikan gaji pegawai. Metode yang dipilih dan digunakan adalah Multi-objective Optimization on The Basis of Ratio Analysis (MOORA). Alasan pemilihan metode ini karena MOORA memiliki tingkat selektifitas yang baik karena dapat menentukan tujuan dari kriteria yang bertentangan [1]. Prosedur MOORA dipandang cocok untuk memberikan solusi bagi permasalahan ini karena karakter permasalahan yang dihadapi bersifat semi terstruktu, data berjenis kuantitatif dan pembobotan telah dihasilkan dari diskusi oleh pihak-pihak terkait [5]. Pada penelitian sebelumnya, metode MOORA banyak diteliti oleh peneliti-peneliti seperti [6][7][8][9][10][11][12][13][14][15].

\section{Tinjauan Pustaka}

\subsection{Konsep dasar MOORA}

Menurut Samuel Manurung (2018) Metode MOORA adalah metode yang diperkenalkan oleh Brauers dan Zavadkas (2006). Metode ini pertama kali digunakan oleh Brauers (2003) dalam suatu pengambilan dengan multi-kriteria. Metode MOORA banyak diaplikasikan dalam beberapa bidang seperti manajemen, ekonomi, design jalan, dll. Pendekatan yang dilakukan MOORA didefinisikan sebagai suatu proses secara bersamaan guna mengoptimalkan dua atau lebih yang saling bertentangan pada beberapa kendala [2].

\subsection{Konsep Sistem Pendukung Keputusan}

Menurut Mesran (2018) Sistem Pendukung Keputusan merupakan system berbasis komputer yang mampu menyelesaikan masalah dengan menghasilkan alternatif terbaik untuk mendukung keputusan yang akan diambil oleh pengambil keputusan [3]. Menurut Redian Arnoldus Sina, dkk (2018) Sistem 
pendukung keputusan lebih ditujukan untuk mendukung manajemen dalam melakukan pekerjaan yang bersifat analitis dalam situasi yang kurang terstruktur dan dengan kriteria yang kurang jelas [4].

\section{Hasil dan Pembahasan}

Pihak manajemen AMIK dan STIKOM Tunas Bangsa terkadang merasa sedikit kesulitan dalam menentukan siapa-siapa pegawai yang berhak naik gaji dengan peringkat masing-masing. Berdasarkan permasalahan tersebut di atas maka dibuat sebuah solusi yang bisa digunakan untuk membantu pihak manajemen dalam menentukan besar kenaikan gaji pegawai berdasarkan ranking yang diperoleh pegawai tersebut. Proses yang dilakukan pada MOORA memerlukan kriteria-kriteria yang mempengaruhi peserta (alternatif) dalam perhitungan kriteria (C) seperti yang terlihat pada table berikut:

Table 1. Kriteria

\begin{tabular}{|c|c|c|}
\hline Kriteria & Keterangan & Tipe \\
\hline C1 & Pendidikan & Benefit \\
\hline C2 & Masa Kerja & Benefit \\
\hline C3 & Kinerja & Benefit \\
\hline
\end{tabular}

Untuk tipe dari masing-masing kriteria, semuanya bertipe benefit. Artinya, semakin tinggi pendidikan, masa kerja dan nilai kinerja seorang pegawai maka semakin tinggi peluang kenaikan gaji pegawai. 
Tabel 2. Menentukan Kriteria Pendidikan

\begin{tabular}{|c|c|c|}
\hline Pendidikan & Nilai & Bobot \\
\hline SMA & 5 & \multirow{2}{*}{40} \\
\hline D3-S1 & 15 & \\
\hline S2-S3 & 20 & \\
\hline
\end{tabular}

Tabel 3. Menentukan Kriteria Masa Kerja

\begin{tabular}{|c|c|c|}
\hline $\begin{array}{c}\text { Tahun } \\
\text { Tahun }\end{array}$ & Nilai & Bobot \\
\hline $\begin{array}{c}>=5 \\
\text { Tahun }\end{array}$ & 10 & \multirow{2}{*}{30} \\
\hline $\begin{array}{c}>=1 \\
\text { Tahun }\end{array}$ & 5 & \\
\hline
\end{tabular}

Tabel 4. Menentukan Kriteria Kinerja

\begin{tabular}{|l|l|c|}
\hline \multicolumn{1}{|c|}{ Perolehan } & \multicolumn{1}{|c|}{ Nilai } & Bobot \\
\hline$>=85$ & 12 & 30 \\
\hline$>=70$ & 10 & \\
\hline$>=60$ & 8 & \\
\hline
\end{tabular}


Sistem Pendukung Keputusan Penentuan Rangking Kenaikan Gaji Staff dan Karyawan

Tabel 5. Sampel data pegawai AMIK dan STIKOM Tunas Bangsa yang akan diberikan kenaikan gaji berdasarkan ranking yang diperoleh

\begin{tabular}{|c|c|c|c|}
\hline Alternatif & $\mathrm{C} 1$ & C2 & C3 \\
\hline $\begin{array}{c}\text { Muhammad } \\
\text { Irfan }\end{array}$ & $\begin{array}{l}\text { S2 } \\
(20)\end{array}$ & $\begin{array}{c}3 \text { Tahun } \\
\text { (5) }\end{array}$ & $\begin{array}{c}83 \\
(10)\end{array}$ \\
\hline $\begin{array}{l}\text { Rendy } \\
\text { Ananta }\end{array}$ & $\begin{array}{l}\text { D3 } \\
(15)\end{array}$ & $\begin{array}{c}5 \text { Tahun } \\
\text { (10) }\end{array}$ & $\begin{array}{l}90 \\
(12)\end{array}$ \\
\hline $\begin{array}{c}\text { Reza } \\
\text { Ardian }\end{array}$ & $\begin{array}{l}\text { D3 } \\
(15)\end{array}$ & $\begin{array}{c}1 \text { Tahun } \\
(5)\end{array}$ & $\begin{array}{l}87 \\
(12)\end{array}$ \\
\hline $\begin{array}{l}\text { Nafisah } \\
\text { Adelia }\end{array}$ & $\begin{array}{l}\text { S1 } \\
(15)\end{array}$ & $\begin{array}{c}6 \text { Tahun } \\
(10)\end{array}$ & $\begin{array}{c}75 \\
(10)\end{array}$ \\
\hline $\begin{array}{l}\text { Nadhirah } \\
\text { Fatin }\end{array}$ & $\begin{array}{l}\text { S1 } \\
(15)\end{array}$ & $\begin{array}{c}2 \text { Tahun } \\
\text { (5) }\end{array}$ & $\begin{array}{c}78 \\
(10)\end{array}$ \\
\hline Ayu Fitria & $\begin{array}{l}\text { SMA } \\
\text { (5) }\end{array}$ & $\begin{array}{l}9 \text { Tahun } \\
\text { (10) }\end{array}$ & $\begin{array}{c}71 \\
(10)\end{array}$ \\
\hline $\begin{array}{c}\text { Budi } \\
\text { Raharjo }\end{array}$ & $\begin{array}{c}\text { SMA } \\
(5)\end{array}$ & $\begin{array}{c}10 \text { Tahun } \\
\text { (15) }\end{array}$ & $\begin{array}{l}86 \\
(12)\end{array}$ \\
\hline
\end{tabular}

Setelah nilai-nilai dari data sampel diperoleh, selanjutnya dibuat matrik dari nilai data sample dari tabel 4 di atas. 


$\left[\begin{array}{rrc}20 & 5 & 10 \\ 15 & 10 & 12 \\ 15 & 5 & 12 \\ 15 & 10 & 10 \\ 15 & 5 & 10 \\ 5 & 10 & 10 \\ 5 & 15 & 12\end{array}\right]$

Normalisasi matriks untuk kolom 1

Normalisasi matriks ini dibuat untuk mencari nilai dari masingmasing alternatif pada kriteria 1 (C1). Dan diperoleh nilai seperti data seperti tampilan di bawah berikut:

$$
\begin{aligned}
X_{11}= & \frac{20}{\sqrt{20^{2}+15^{2}+15^{2}+15^{2}+15^{2}+5^{2}+5^{2}}} \\
& =20 / \sqrt{1350} \\
& =20 / 36.742=0.544
\end{aligned}
$$

$X_{21}=15 / 36.742=0.408$

$X_{31}=15 / 36.742=0.408$

$X_{41}=15 / 36.742=0.408$

$X_{51}=15 / 36.742=0.408$

$X_{61}=5 / 36.742=0.136$

$X_{71}=5 / 36.742=0.136$

Normalisasi Matriks untuk kolom 2

Normalisasi matriks ini dibuat untuk mencari nilai dari masingmasing alternatif pada kriteria 2 (C2). Dan diperoleh nilai seperti data seperti tampilan di bawah berikut:

$$
\begin{aligned}
X_{21} & =\frac{5}{\sqrt{5^{2}+10^{2}+5^{2}+10^{2}+5^{2}+10^{2}+15^{2}}} \\
& =5 / \sqrt{600} \\
& =5 / 24.494=0.204 \\
X_{22} & =10 / 24.494=0.408
\end{aligned}
$$


$X_{23}=5 / 24.494=0.204$

$\mathrm{X}_{24}=10 / 24.494=0.408$

$\mathrm{X}_{25}=5 / 24.494=0.204$

$X_{26}=10 / 24.494=0.408$

$\mathrm{X}_{27}=15 / 24.494=0.612$

Normalisasi Matriks untuk kolom 3

Normalisasi matriks ini dibuat untuk mencari nilai dari masingmasing alternatif pada kriteria 3 (C3). Dan diperoleh nilai seperti data seperti tampilan di bawah berikut:

$$
\begin{aligned}
X_{31} & =\frac{10}{\sqrt{10^{2}+12^{2}+12^{2}+10^{2}+10^{2}+10^{2}+12^{2}}} \\
& =10 / \sqrt{832} \\
& =10 / 28.844=0.346 \\
X_{32} & =12 / 28.844=0.416 \\
X_{33} & =12 / 28.844=0.416 \\
X_{34} & =10 / 28.844=0.346 \\
X_{35} & =10 / 28.844=0.346 \\
X_{36} & =10 / 28.844=0.346 \\
X_{37} & =12 / 28.844=0.416
\end{aligned}
$$

Dari hasil perhitungan seluruh normalisasi yang telah dilakukan terhadap semua alternative terhadap seluruh kriteria, selanjutnya dibuat Matriks Normalisasi MOORA seperti berikut ini:

$\left[\begin{array}{ccc}0.544 & 0.204 & 0.346 \\ 0.408 & 0.408 & 0.416 \\ 0.408 & 0.204 & 0.416 \\ 0.408 & 0.408 & 0.346 \\ 0.408 & 0.204 & 0.346 \\ 0.136 & 0.408 & 0.346 \\ 0.136 & 0.612 & 0.416\end{array}\right]$

HASIL peringkangan nya seperti berikut:

$\mathrm{Y}_{1}=0.544+0.204+0.346=1.094=4$ 
$\mathrm{Y}_{2}=0.408+0.408+0.416=1.232=1$

$\mathrm{Y}_{3}=0.408+0.204+0.416=1.028=5$

$\mathrm{Y}_{4}=0.408+0.408+0.346=1.162=3$

$\mathrm{Y}_{5}=0.408+0.204+0.346=0.958=6$

$\mathrm{Y}_{6}=0.136+0.408+0.346=0.89=7$

$\mathrm{Y}_{7}=0.136+0.612+0.416=1.164=2$

\section{Kesimpulan}

Berdasarkan kesimpulan di atas, maka dapat disimpulkan bahwa

a. Sistem yang saat ini dilakukan terkait kenaikan gaji pegawai masih sangatlah lemah dan memiliki banyak kekurangan dan kalemahan, dikarenakan pimpinan masih merasa sedikit kesulitan dalam menentukan siapa pegawai yang berhak naik gaji berdasarkan factor-faktor tertentu.

b. Sistem Pendukung Keputusan ini dibuat dengan Metode MOORA sangat lah cocok untuk mennyelesaikan permasalahan tersebut. Hasil yang diperoleh sangat lah baik dan cocok dalam menentukan pegawai mana yang layak dinaikkan gajinya.

c. Sistem Pendukung Keputusan ini sebatas memberikan hasil berupa perankingan pegawai yang layak naik gaji. Namun demikian, ranking berapa saja yang berhak naik gaji dan besar jumlah nominal kenaikan gaji nya tetap diputuskan oleh pimpinan AMIK dan STIKOM Tunas Bangsa Pematangsiantar.

\section{Daftar Pustaka}

[1] Syaiful Rokhman, Imam Fahrur Rozi, Rosa Andrie Asmara. 2017. "Pengembangan Sistem Penunjang Keputusan penentuan UKT Mahasiswa dengan menggunakan metode MOORA". Jurnal Informatika Polinema (JIP). Vol (3): 36-42. 
[2] Samuel Manurung. 2018. “Sistem Pendukung Keputusan Pemilihan Guru dan Pegawai terbaik menggunakan metode MOORA". Jurnal SIMETRIS. Vol (9): 701-706.

[3] Mesran, Swandi Dedi Arnold Pardede, Arahman Harahap, Andysah Putera Utama Siahaan. 2018. “Sistem Pendukung Keputusan Pemilihan Peserta Jaminan Kesehatan Masyarakat (Jamkesmas) menerapkan Metode MOORA". Jurnal Media Informatika Budidarma. Vol (2): 16-22.

[4] Redian Arnoldus Sina, Kornelis Letalay, Dony M. Sihotang. 2018. "Penerapan metode Multi Factor Evaluation Process pada aplikasi sistem pendukung keputusan penentuan permohonan pinjaman nasabah pada Koperasi simpan pinjam Gloria". J-ICON. Vol (6): 35-39.

[5] Haryanto. 2018. "Pembuatan Aplikasi Sistem Penunjang Keputusan untuk pemilihan penerima beasiswa siswa KMS dengan Metode MOORA". Jurnal Informa Politeknik Indonusa Surakarta. Vol (4): 10-19.

[6] Chintya Irwana, dkk, 2018, "SPK : Analisa Metode MOORA Pada Warga Penerima Bantuan Renovasi Rumah, JTI Vo. 10 No.1.

[7] Aldi Muharsyah, dkk, 2018, “Sistem Pendukung Keputusan Penerimaan Jurnalis Menerapkan Multi Objective Optimization On The Basis of Ratio Analysis (MOORA), JURIKOM Vol. 5 No. 1.

[8] Indra Hidayatulloh, dkk, 2017, "Metode MOORA dengan Pendekatan Price Quality Ratio Untuk Rekomendasi Pemilihan Smartphone", Proceeding SINTAK.

[9] Shankar Chakraborty, 2011, "Application of The MOORA Method for Decision Making In Manufacturing Environment", Int J Adv Manuf Technol. 
[10] Willem K. Brauers, dkk, 2009, "Robustness Of The MultiObjective MOORA Method With A Test For The Facilities Sector", Baltic Journal On Suistainability.

[11] Willem K. Brauers, 2014, “Location of Seaport by MOORA Optimization, International Conference on Advanced Logistics and Transport.

[12] Prasad Karande, dkk, 2012, "Application of MultiObjective Optimization on The Basis of Ratio Analysis (MOORA) Method for Materials Selection", Materials and design.

[13] Willem K. Brauers, dkk, 2006, "The MOORA Method and Its Application to Privatization in A Transition Economy, Control and Cybernatics.

[14] Willem K. Brauers, dkk, 2010, "Multi Objective Contractor 's Ranking By Applying The MOORA Method", Journal of Business Economics and Management.

[15] Khairun Nisa Arifin Nur, Sundari Retno Andani, 2017, "Sistem Pendukung Keputusan Pemilihan Operator Seluluer Menggunakan Metode Multi-Objective Optimization On The Basis Of Ratio Analysis (MOORA)", KOMIK (Konferensi Nasional Teknologi Informasi dan Komputer), Volume I, Nomor 1. 